\title{
CAN BEADS STIMULATE A DECIDUAL RESPONSE IN THE MOUSE UTERUS?
}

\author{
ANNE McLAREN \\ A.R.C. Institute of Animal Genetics, Edinburgh \\ (Received 3rd Fuly 1967)
}

The first indication of a local decidual response to the presence of blastocysts in the mouse uterus is the appearance of Pontamine Blue reactivity at the end of the 4th day of pregnancy (Orsini \& McLaren, 1967; Finn \& McLaren, 1967). The factor inducing this response is unknown. The time relations make it unlikely that the appearance of $\mathrm{W}$-bodies in the uterine endometrium is involved. Blandau (1949) claimed that in rats, though not in guinea-pigs, glass beads inserted into a pseudopregnant uterus during the sensitive period were sufficient to stimulate a decidual response, suggesting that, in pregnancy, the physical pressure of the blastocyst in the uterine lumen acts as the inducing factor. The present study was designed to show whether beads would stimulate a decidual response in mice.

Females of the randomly bred $Q$ strain were mated to vasectomized $Q$ males. The day on which a vaginal plug was found was designated the 1st day of pseudopregnancy. Spherical beads of glass 65 to $120 \mu$ in diameter, or acrylic polymer MG (Diakon, ICI) 70 to $150 \mu$ in diameter, in $10 \%$ calf serum in phosphate buffered saline, were injected into the right uterine horn on the 3rd or 4th day of pseudopregnancy, by the technique used to transfer fertilized eggs (McLaren \& Michie, 1956). Sensitivity to the induction of deciduomata by the injection of $0.02 \mathrm{ml}$ of air into the uterus begins on the 3rd day, and is maximal on the 4th and 5th days of pseudopregnancy (Orsini \& McLaren, unpublished). Females were killed $15 \mathrm{~min}$ after receiving $0.2 \mathrm{ml}$ of $0.5 \%$ Pontamine Sky Blue intravenously, and the uteri were either flushed to recover the beads, or fixed in formol saline and cleared in benzyl benzoate (Orsini, 1962) so that the beads could be identified in situ. Control groups received 4thday blastocysts, or $10 \%$ serum alone. Some of the uteri containing Diakon beads, and all those receiving blastocysts, were examined histologically.

The results are shown in Table 1. The high yield of beads recovered suggests that the relatively low recovery rate of blastocysts was not due to failure to get the blastocysts into the uterus. However, unlike the blastocysts, neither the glass nor the Diakon beads were effective in stimulating any Pontamine Blue sensitivity, even after $48 \mathrm{hr}$. The occasional Pontamine Blue areas which did not contain beads, presumably represent a response to the operation itself, since similar empty areas were seen in the uteri receiving blastocysts or serum.

When the cleared uteri were examined, the beads were observed sometimes spread out along the uterine horn, but more usually clumped together at either the top or the bottom of the horn. Histological study of uteri which received 
Diakon beads revealed that some of the beads had passed through the uterine epithelium and into the stroma, while some were situated at the antimesometrial end of the uterine lumen as are blastocysts (Pl. 1, Figs. 1 to 5). In neither

TABLE 1

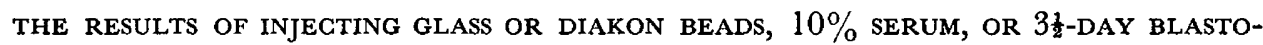
CYSTS, INTO THE RIGHT UTERINE HORNS OF PSEUDOPREGNANT FEMALE MICE

\begin{tabular}{|c|c|c|c|c|c|c|c|}
\hline \multirow{3}{*}{$\begin{array}{l}\text { Time of } \\
\text { injection } \\
\text { (days p.c.) }\end{array}$} & \multirow{3}{*}{$\begin{array}{l}\text { Time of } \\
\text { autopsy } \\
\text { (days p.c.) }\end{array}$} & \multirow{3}{*}{ Injected } & \multirow{3}{*}{$\begin{array}{l}\text { No. of } \\
\text { females }\end{array}$} & \multirow{2}{*}{\multicolumn{2}{|c|}{$\begin{array}{c}\text { No. of beads or } \\
\text { blastocysts }\end{array}$}} & \multicolumn{2}{|c|}{ P.B. areas* } \\
\hline & & & & & & \multirow{2}{*}{$\begin{array}{l}\text { Containing } \\
\text { beads or } \\
\text { blastocysts }\end{array}$} & \multirow{2}{*}{ Empty } \\
\hline & & & & Injected & Recovered & & \\
\hline $2 \frac{1}{2}$ & $4 \frac{1}{2}$ & Glass beads & 8 & 48 & $32(67 \%)$ & 0 & 2 \\
\hline $\begin{array}{l}3 \frac{1}{2} \\
3 \frac{1}{2} \\
3 \frac{1}{2} \\
3 \frac{1}{2}\end{array}$ & $\begin{array}{l}4 \frac{1}{2} \\
4 \frac{1}{2} \\
5 \frac{1}{2} \\
5 \frac{1}{2}\end{array}$ & $\begin{array}{l}\text { Glass beads } \\
\text { Diakon beads } \\
\text { Glass beads } \\
\text { Diakon beads }\end{array}$ & $\begin{array}{r}14 \\
3 \\
2 \\
2\end{array}$ & $\begin{array}{l}83 \\
17 \\
12 \\
12\end{array}$ & $\begin{array}{c}79(95 \%) \\
13(76 \%) \\
12(100 \%) \\
9(75 \%)\end{array}$ & $\begin{array}{l}0 \\
0 \\
0 \\
0\end{array}$ & $\begin{array}{l}3 \\
2 \\
0 \\
1\end{array}$ \\
\hline $\begin{array}{l}3 \frac{1}{2} \\
3 \frac{1}{2} \\
3 \frac{1}{2}\end{array}$ & $\begin{array}{l}4 \frac{1}{2} \\
4 \frac{1}{2} \\
4 \frac{1}{2}\end{array}$ & $\begin{array}{l}\text { Serum } \\
\text { Serum and air } \\
\text { Blastocysts }\end{array}$ & $\begin{array}{r}27 \\
7 \\
9\end{array}$ & $\overline{-}$ & $\begin{array}{c}\overline{-} \\
33(38 \%)\end{array}$ & $\overline{-}$ & $\begin{array}{l}3 \\
5 \\
2\end{array}$ \\
\hline
\end{tabular}

* P.B. = Pontamine Blue.

case was any histological evidence of decidualization observed. By contrast, the uteri receiving blastocysts showed local oedema of the stroma, and an early decidual reaction, $24 \mathrm{hr}$ after transfer (Pl. 1, Fig. 2). The 'empty' Pontamine Blue areas showed an accumulation of secretion, and, by the 6 th day, massive decidualization (Pl. 1, Fig. 6).

\section{EXPLANATION OF PLATE 1}

Transverse sections $(8 \mu)$ of mouse uteri. Fig. 2 : fixed in AFA (alcohol-formol-acetic); Figs. 1, 3 to 6 : fixed in formol-saline. All stained with haematoxylin and eosin.

Fig. 1. 'Implantation chamber' left by Diakon bead at antimesometrial end of uterine lumen. Beads transferred to pseudopregnant recipient, $3 \frac{1}{2}$ days p.c.; recipient killed 2 days later. Uterine stroma shows no indications of any decidual response, $\times 90$.

Fig. 2. Implantation chamber containing blastocyst at antimesometrial end of uterine lumen. Blastocysts from donors $3 \frac{1}{2}$ days p.c. transferred to pseudopregnant recipient $3 \frac{1}{2}$ days p.c.; recipient killed 1 day later (at 18.00 hours on 5 th day). Uterine stroma already shows marked decidual response. $\times 90$.

FIG. 3. High power view of 'implantation chamber' formed by Diakon bead at antimesometrial end of uterine lumen. Beads transferred to pseudopregnant recipient, $3 \frac{1}{2}$ days p.c.; recipient killed 1 day later. Uterine epithelium is flattened, owing to physical distension by the bead, but shows no signs of proliferation or degeneration. $\times 320$.

Fig. 4. Three holes in stroma left by Diakon beads which migrated from the uterine lumen. Beads transferred to pseudopregnant recipient, $3 \frac{1}{2}$ days p.c.; recipient killed 1 day later. $\times 85$.

FIg. 5. High power view of hole in stroma left by Diakon bead. The uterine horn is the same one which contained the chambers illustrated in Figs. 1 and 4. Note lack of any uterine reaction. $\times 325$.

Fic. 6. 'Implantation chamber' at antimesometrial end of uterine lumen, from Pontamine Blue area in same uterine horn as chamber illustrated in Fig. 1. This chamber was not associated with a Diakon bead, but contains secretion, possibly the result of infection. The uterine lumen and mesometrium is out of view, to the upper right. The epithelium around the chamber has degenerated, and the stroma shows a strong decidual cell reaction. $\times 320$. 

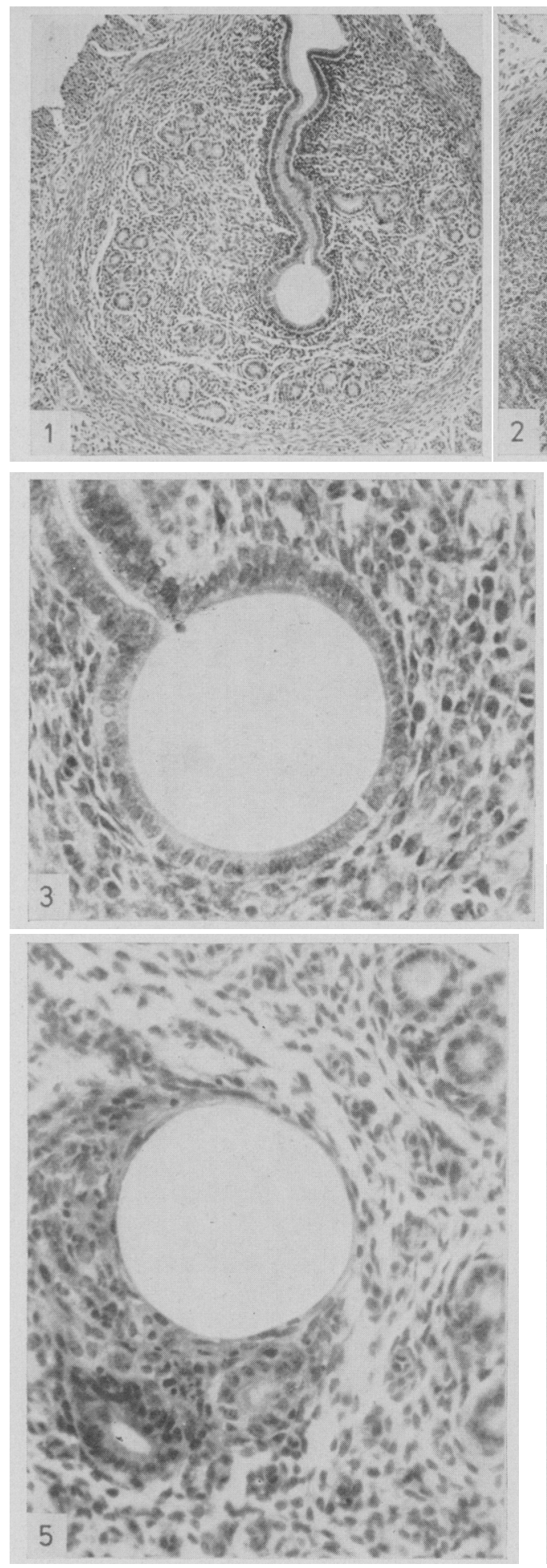

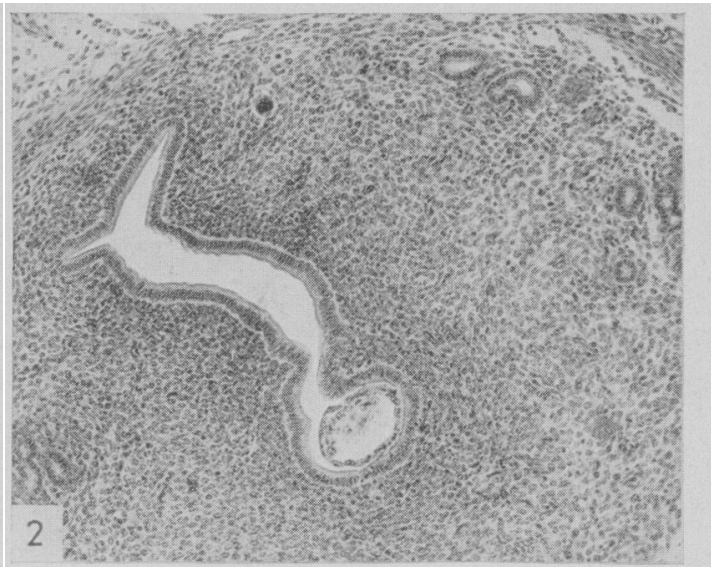

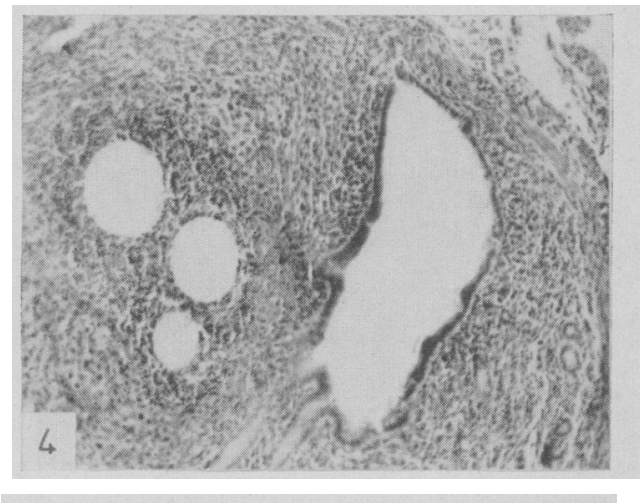

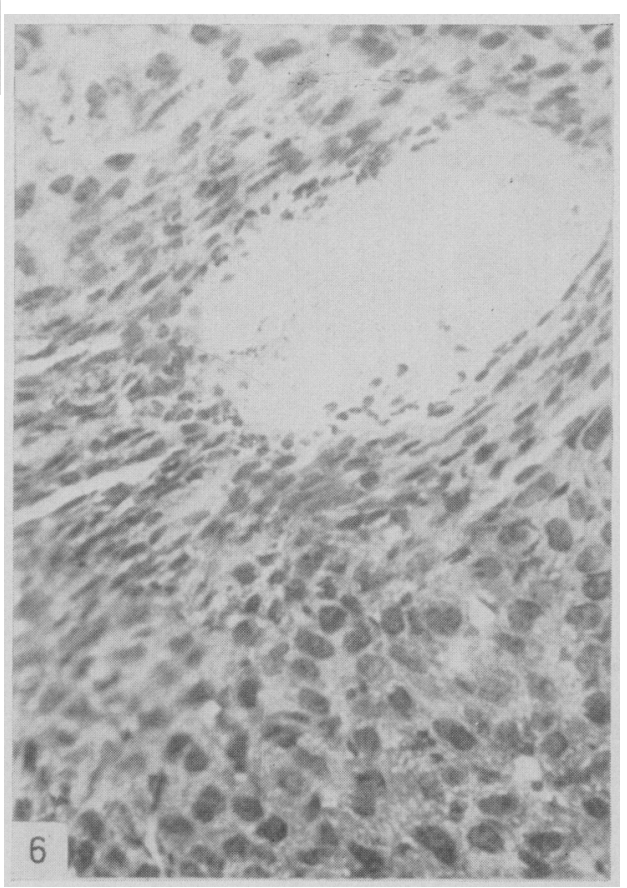

(Facing p. 314) 
Unfertilized eggs do not normally evoke Pontamine Blue sensitivity in mice (McLaren \& Orsini, 1968). Alloiteau (1958) observed that unfertilized eggs became capable of stimulating a decidual response in rat uteri if an excess of progesterone was given. Ten female mice were therefore given $2.5 \mathrm{mg}$ of progesterone (Progestin, Organon) subcutaneously from the 3rd day of pseudopregnancy onwards, and fifty-six glass beads were transferred to the right horn of each on the 3rd or 4th day. Forty-eight were identified in situ; no Pontamine Blue areas were seen in any of the uteri.

The apparent difference between these results and those of Blandau (1949) is consistent with the fact that the uterus is much less sensitive to trauma in mice than in rats. For instance, Finn (1965) found that the intraluminal injection of saline or the intraperitoneal injection of pyrathiazine, both potent inducers of deciduomata in rats, evoked little or no decidual response in pseudopregnant mice.

We may conclude that, whatever may be the situation in the rat, in the mouse it is not the physical distension of the uterine lumen by the blastocyst which induces the decidual response.

I would like to thank Dr P. F. Kraicer, Weizmann Institute of Science, Israel, and Professor P. M. B. Walker, Zoology Department, Edinburgh University for providing me with glass beads, and the Plastics Division of Imperial Chemical Industries Ltd for supplying the Diakon particles. I gratefully acknowledge financial support from the Ford Foundation.

\section{REFERENCES}

Alloiteau, J. J. (1958) L'œuf non fécondé peut-il provoquer une réaction déciduale chez la ratte? Revue fr. Étud. clin. biol., 974.

BLANDau, R. J. (1949) Embryo-endometrial interrelationship in the rat and guinea pig. Anat. Rec. 104,331 .

Frns, C. A. (1965) Oestrogen and the decidual cell reaction of implantation in mice. F. Endocr. 32, 223.

FinN, C. A. \& MaLaren, A. (1967) A study of the early stages of implantation in mice. F. Reprod. Fert. 13, 259.

McLaren, A. \& Mrahre, D. (1956) Studies on the transfer of fertilized mouse eggs to uterine fostermothers. 1. Factors affecting the implantation and survival of native and transferred eggs. 7. exp. Biol. 33, 394.

McLaren, A. \& OrsinI, M. W. (1968) The fate of unfertilized eggs in mice. J. Reprod. Fert. 15, 181.

Orsini, M. W. (1962) Technique of preparation, study and photography of benzyl-benzoate cleared material for embryological studies. F. Reprod. Fert. 3, 283.

Orsini, M. W. \& MaLaren, A. (1967) Loss of the zona pellucida in mice, and the effect of tubal ligation and ovariectomy. F. Reprod. Fert. 13, 485. 